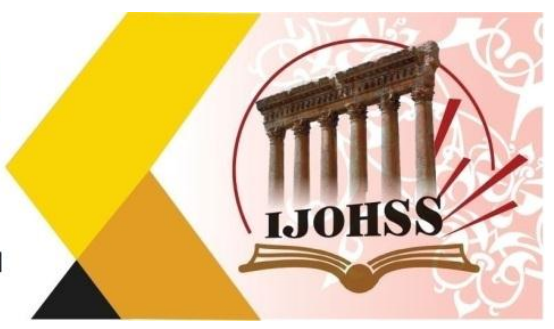

\title{
The Representation of American Dream in Lorrain Hansberry's A Raisin in the Sun
}

\author{
Abdulrahman Sulaiman Khaleel \\ Department of English \\ College of Arts \\ AL-Iraqia University - Iraq \\ Abudlrahman2000@gmail.com \\ Abdulrahman.khaleel@aliraqia.edu.iq
}

\begin{abstract}
In this article, the aim is to analyze theme of 'American Dream' within Lorrain Hansberry's A Raisin in the Sun. Such a theme has appeared roughly as a recurring theme of debate in literary works and drama undoubtedly is not an exception of that. This paper tries to figure out an answer for the question in which how is the American Dream exposed according to every character within the play? Playwrights attempted through their artistic productions and reproductions to exhibit such a theme while writing dramas to enlighten the image of America on a societal ground. As for the play itself, the spread of African- American ideas in literature is made use of in socially depicting humans' rights. Lorrain Hansberry being one of the prominent black writers, has been telling the world concerning the Black people's pain and awes. The distresses, thwarting and domination of the subjugated Africans are exhibited in her writings. Throughout the drama, the protagonist is shown as controlled by the White and the way she strived being discriminated. The methodology of this article is a textual analysis for the excerptions under investigation making use of the Theory of Racism and Racial Discrimination to comprehend the sociological status of the characters in the play. It is found that Black people - under the siege of the Whites have suffered the discrimination due to oppression, color and social status.
\end{abstract}

Keywords: American Dream, Lorrain Hansberry, A Raisin in the Sun, The Black people, Domination. 


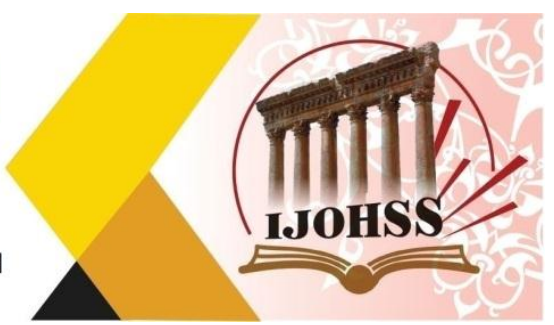

\section{Introduction}

In her masterpiece, A Raisin in the Sun (1959) Lorrain Hansberry is skillfully depicts the theme of the American Dream. The play itself, is a reflection of the Youngers' life, which appears as a distinctive African-American family during the time between World War II and the radical movement of the sixties. Who lived in a Jewish neighborhood, Southside of Chicago? The play is a kind of record for the struggles suffered by the Younger to uncover a place for their own as well as the aim within this away from putting an end to the sensitive relations within the family. Through the depiction of the African-American family and its predicament, which is depicted in both in an accurate and a realistic way as a dream had been delayed by the family members. This situation is well-manifested by which even small Travis despite the fact that his dream did not have a direct statement. This family's dreams though different and somewhat slight, have appeared to be dried up as for a raisin in the sun. For example, the marriage of Walter Lee and Ruth has been through such a situation of drying up as well. The significance of their marriage did not last longer as a dream that was delayed and lost its value. Even the suffering for joyfulness dried up due to their focus on remaining alive only.

\section{Review of Literature}

A Raisin in the Sun has had some comments and criticisms by which it may assist in analysing the play. In terms of modern realist, David Scanlan (1988) states that a drama like A Raisin in the Sun is "intended to give its audience a picture of life as it is. The ending of A Raisin in the Sun resolves conflicts within the Younger family, but the outside world is still a potential obstacle" ( $p, 46)$. Here, Scanlan intends to show that A Raisin in the Sun is a description of the answer meant for the problems of the internal realistic life of the Youngers, however, the family encounters the society of the Whites as representing the external world.

While the Merriam-Webster's Encyclopedia of Literature posits that A Raisin in the Sun represented an intuitive study in relation to the strains of a black family from the working-class when it is presented with a chance for a better life (STAFF, 1995: 519). Mama, Ruth and Walter were a hard workers striving for a better life. "A Raisin in the Sun was a revolutionary work for its time. Lorraine Hansberry creates in the Younger family one of the first honest depictions of a black family on an American stage, in an age when predominantly black audiences simply did not exist. Before A Raisin in the Sun, black plays usually were comedic.

As for the 'American Dream' it is commonly known by Americans as a popularized phrase presented by James Truslow Adams (1878-1949) in his book of 1931 'The Epic of America'. In this book, the writer talked about the Americans faith in which each citizen would have his / her chance to gain self-fulfillment irrespective to their 


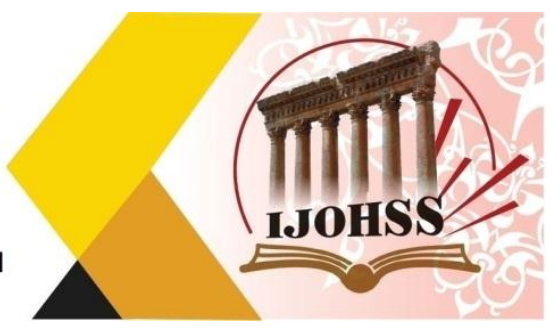

birth or position. On the contrary, ironically, Edward Albee used this phrase in his 'The American Dream' of (1961). Adams defined the American Dream by saying:

"That dream of a land in which life should be better and richer and fuller for every man, with opportunity for each according to his [or her] ability or achievement. It is a difficult dream for the European upper classes to interpret adequately, and too many of us ourselves have grown weary and mistrustful of it. It is not a dream of motor cars and high wages merely, but a dream of social order in which each man and each woman shall be able to attain to the fullest stature of which they are innately capable, and be recognized by others for what they are, regardless of the fortuitous circumstances of birth or position.” (p.415)

The tracing of the theme of American Dream might be seen back from the time when the New Land was discovered. For Ursula Seiler (2017) in 'The Promised Land', the American Dream was associated with the historical discovery of America. She stated that America was desired to be discovered by many discoverers:

"America was long known to the world's initiates. They determined when it might be 'discovered'. They chose the discoverer. They knew the plan for the New World and its purpose: to become the leading nation in the promised Golden Age." (p.15)

Religion is considered as a more agitating the theme of the American Dream as compared with material issues. It is linked with what is known as the 'heretical' clique of the Albigensians' (1). For them "a pure chaste of life meant to be poor in worldly goods, to shun no work, to kill no creature, including animals, which is why they were vegetarians, and to use all means to oppose the 'God of darkness', the Tempter".

There was a kind of link that brought the 'American Dream' and the land together. That is why there always had been promises, as commented by Schlesinger (1948) "from the first voyage and the first ship there were promises." (p. 286). The newly discovered land represented man's ambitions. A new life is represented by America as a new land for a freer life as well as an assurance for divine goodness, material happiness, and the pursuit of fairness. Such motivations cause to establish the new promised, that stand as an image of "the City on the Hill..., [and] the Land of the New Start." (Bradbury \& Temperley, 1998: p.2). What is nowadays knows as America is seen and upheld to be an "Empire of Liberty" of prosperous future. Therefore, as the American Dream's foundation might be started in the Declaration of Independence, in 1776:

1 - The Albigensians had been members of a Cathartic sect who inhabited the southern part of France during the $11^{\text {th }}$ century. Later on during $13^{\text {th }}$ century of Crusade rule, they were exterminated by (Albigensians Crusade). For more information, visit, http://www.dictionary.com/browse/albigensian. 
العدد (28) ديسمبر 2021

Volume (28) December 2021

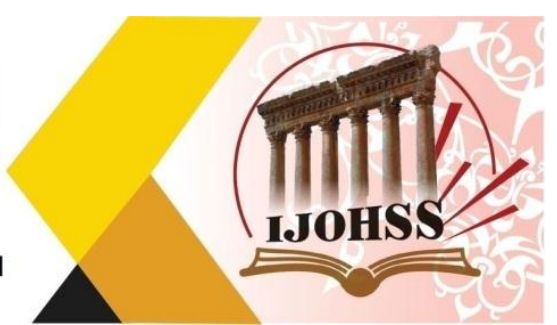

"We hold these truths [of the American Dream] to be self-evident, that all men are created equal, that they are endowed by their Creator with certain unalienable rights, that Among these are life, liberty, and the pursuit of happiness." (Sunstein, 2003: p.1).

\section{What is meant by the American Dream?}

As it is common for the public, the American Dream with all its connotation has undergone changes by the passage of time. Nowadays' beliefs in a simple way designate to show capability via involvement socially and economically for all those who supposed to share the achieved prosperity. The dream as it suggests, encompasses everyone's opportunity regardless age, gender and color. It is the chance for children to happily grow up and fairly get their good education and jobs away from all kinds of artificially set hurdles. It means everyone's chance to set his/her individual decisions and selections short of whatever restricts citizens in the light of their ethnicity, caste, class, race or religion. (Bloom \& Hobby, 2009).

Modern days have taken the accountability to change such a dream and what happened is that it was only a matter of getting rich, more that "the promise that all Americans have a reasonable chance to achieve success as they define it - material or otherwise - through their own efforts, and to attain virtue and fulfillment through success". (Hochschild, 1996). The American Dream is among the most important movements that has played its critical role in the history of American literature. It is not only a mere reference to the one's identity, it is further a reference to the American society that has been through times of anguish to get rid of the authorities of the orthodox religious conventions. Moreover, its horizon has been a boundless one as for in poetry, novel, drama, and so on. Besides, the American Dream can have the ability to be dived deep within the varied colors of the American literature.

\section{The American Dream as a Theory}

The land in America was characterized by fertility in which people called it 'the New World' and this was the beginning of a new golden era for a new nation: America. Different countries participated in pushing their people to come to the New World where there were opportunities of a better life with ease and comfort. Eventually, the existence of such a New World was real in a land of possibilities. Commenting on the idea of good opportunities, Leo Lemay (1989) mentions in 'An Early American Reader':

"The very name calls the New World an idyllic myth, the start of a new golden age, a new beginning for a new Adam. The name conspired with the idea of nature to ensure that the prevailing myth of the New World would be that of a new Garden of Eden. The New World seemed to promise that mankind could recapture the innocence, joys, and eternal life, as well as the freedom from cares and labour that had existed in the Garden of Eden" ( $p$. $1)$.

Nevertheless, the immigrants' viewpoints posited that the existence of the American Dream was earlier than the discovery of America. In his Literary History of the 


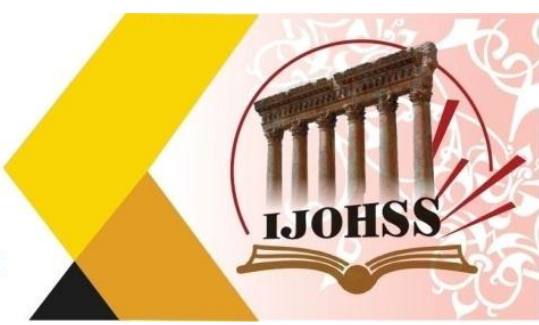

United States, Spiller et al., (1949) said that "As a state of mind and a dream, America had existed long before its discovery. Ever since the early days of civilization, peoples had dreamed of a lost Paradise, of a Golden Age" (p, 192). The outbreak of the mid- $16^{\text {th }}$ century witnessed that the New World was both the age of golden land, by which America was seen as Paradise. People sought their wishes and the mines of gold respectively.

"The Spanish found the New World to be a land of cities and golden treasures, where the natives would work for the colonists who could spend a few adventurous years in America before returning, landed with gold, to Europe" (Lemay, 1989: 3).

The emergence of the term 'American Dream' had been since the coming of the early immigrants in the $17^{\text {th }}$ century to the New Land. "Their coming was attributed to economic, political and religious reasons" (Parillo, 1994: 110). As again stated by Lemay (1985) "There was a myth that a hard workingman could become rich. And the fundamental materialist version of the American Dream was the rags-to-riches story that all early Americans knew about it" $(p, 5)$. In other words, as it is believed that chances for everyone are given by America and these include the deprived to secure their economy, which urged other people to go to America. It is also believed by the Americans that working hard, will make them be successful. Therefore, it is not the reason they are born rich as stated by Reuslow James Adams (19350 in The Record of America in the following quotation:

"They have wanted to find and built a country in which they could be looked upon what they could make of themselves. They wanted a country in which the prizes and a good life would go to those who could win them and not just be given to those who happened to be born rich or titled or otherwise privileged. This is "the American Dream" $(\mathrm{P}, 4)$

Furthermore, Althen et, al., (2003) in theirs 'American Ways', Americans think of having a freedom in doing and making their own decision. According to the Americans, all people have freedom in making up their minds. Their privacy is guaranteed and everyone is equal in positions. They are also equal in rights and opportunities. These rights and equality is extended to involve children as well by giving them their opportunities in making their choices. As a conclusion, the American Dream is a thought offered by America in terms of opportunities and freedoms for every citizen to enjoy a much better life in variously in forms of life through hard work.

\section{Methodology}

This article adopts the following methodology: presenting an introduction of the technique and the text (i.e. the play being investigated). The principal data was collected using several readings in connection with the theme of the American Dream as reflected in the play itself. Textual analysis is adopted in identifying the said theme (i.e. the American Dream). Such a theme is applied in Lorraine Hansberry's A Raisin 


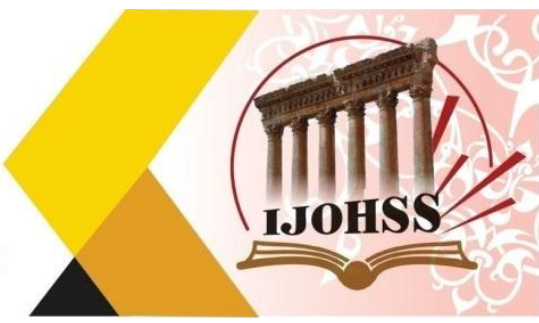

in the Sun (1959) to demonstrate the various examples existed within the text. These examples are enhanced by the researcher, as he uses references from the text itself, or any other critical study(s) achieved in the field of African-American literature.

\section{Research Design}

In fact, any study/research design has to take the proper path by which study/research is carried out. Hence, this article involves the steps adopted by which it is carried out - to say so -.

A. The strategy for data collection.

B. Measuring Data.

C. Analyzing Data

Upon designing any study/research, the $\mathrm{ABCs}$ of that study/research has to be completed by the time both of the topic and problem of research are set. This procedure includes selecting and formulating both the topic and problem. At that point, a suitable outlining of the objective is placed forward. Besides, the skillful definition of the hypothesis - if exits - that is properly framed. At the same time, designing a study/research is to formulate the capability of offering potential answers to the set of proposed questions/queries:

1. What is the concern of the study/research?

2. What is the required set/type of data?

2. What is the goal of the study/research?

3. What are the bases of data?

\section{Research Locale}

This article is written by using the theme of the American Dream as a fundamental issue in African-American literature as associated with Lorraine Hansberry's A Raisin in the Sun as a chief source of data. Furthermore, reviews and analyses - secondary sources - achieved in the area of African-American literature, respectively drama is used to achieve the objective of this article.

\section{Sampling Procedure}

Patton (1989, p100-107) states that for extracting a sample of the study, a specific procedure is to be employed, which involves the following:

i. Purposeful Sampling: it is the way of choosing subjects that is believed thy will offer data of significance. Purposeful sampling has the following types: "maximum variation", "typical case", "critical case" and "extreme or deviant case".

ii. Key Informant: it is a certain person that is believed to offer the most information needed to develop interview questions or to begin snowball sampling.

iii. Snowball Sampling: it is the way to ask participants to offer the names of the data providers.

iv. Convenience: it is simply to ask anyone to whom you can easily reach. 


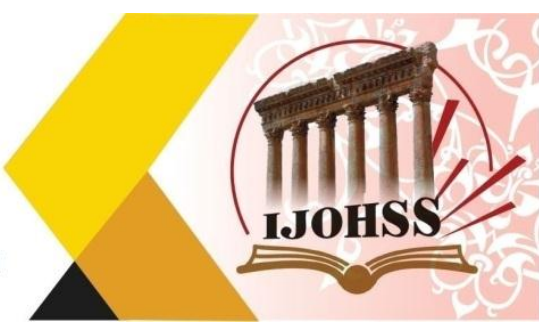

v. Random Table/Random Sampling: it is when all the persons in of the population are equally having the opportunity to be selected. Random procedure is the way of selection. Random procedure such as using random table of numbers.

vi. Stratified Sampling: it is "stratified" which means to choose from varied subgroups. The division of population can be into sub-populations and random samples are taken of each subpopulation. Instance of stratified by gender. If the population has $25 \%$ females and $75 \%$ males, the sample should be chosen randomly by subpopulations and consist of $25 \%$ females and $75 \%$ males.

vii. Whole Population: it is the whole population is used. This is normally true in case of small population.

\section{Data Collection}

Data in this paper is collected from two main streams, the first is the play under examination as a fundamental stream, while the second one is papers, analyses and reviews - as secondary data - written in the field of African-American literature/drama as well as the theme of the American Dream.

\section{Data Analysis}

Data in this paper is analyzed using a textual analysis method, making use of the theory under study as well as selecting some extracts from the assigned text/work to be analyzed according to the principles of the selected theme.

\section{A Raisin in the Sun (1959)}

Lorraine Hansberry's well-known masterpiece 'A Raisin in the Sun' is a three-act drama that was appeared for the first time in 1959. This play was the earlier to be written by a black female playwright and was directed for the Black people (Gale, 2018). This play treats the experiences of the African-Americans earlier than the emergence of the civil rights movement during the 60s. A depiction of a middles-class African-American family is the main theme of 'A Raisin in the Sun'. The said family is attempting to raise itself within the American community. Moreover, much of the play's plot was based on the playwright's personal experience in 1938. At that time, Hansberry's family attempted to dwell among the Whites and for their shock, they were aggressively attacked by those Whites. (Abbotson, 2003). This play was written by Lorraine Hansberry in 1959, when the southerns started to migrate towards the Northern cities, as Chicago. This is the reason behind Hansberry's selecting the play's setting to be Chicago where the Youngers set their goal to live the American Dream. (Hansberry, \& Shay, 1974).

Therefore, scholars in the field of African-American literature praised 'A Raisin in the Sun' as a famous American classic. This play has been translated into thirty languages with its amazing fame and spread all over the world. Nowadays, 'A Raisins in the Sun' is worthy to be Hansberry's masterpiece within the African-American theatre. 


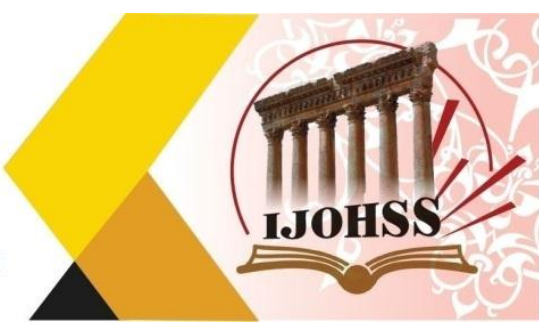

For the previously mentioned reason, it is regarded as a historic innovation that signifies a revolutionary sense in the Black consciousness as well as for women's rights. This issue is well-reflected in the play by the characters of females in which these figures replied variously to their husbands' chauvinism and arrogance as well as their community. (Bernstein, 1999). The well-known newspaper, 'the New York Times', A Raisins in the Sun played a significant role in changing the American theatre persistently with its Broadway opening in 1959 and its twenty-nine-year-old author. James Baldwin (1989) wrote of the play: "Never before in the history of the American theatre had so much truth of black people's lives been seen on the stage." (p.129) since then, 'A Raisin in the Sun' has continued to be an international dramatic classic.

This played displayed a kind of colored and complicated creation presented by Hansberry by which human nature is the man concern. The playwright herself has offered a belief in which a dream that can impulse our ambitions may have the effect in terminating our psyche unless it is appropriately accomplished. Our psyche is in need for a dream to characterize one's dynamic search concerning self-improvement. This search is essential while constantly reconsidering both value and status of one's existence. The plot of the play is drawn as each character's dream has been realized. (Domina \& Hansberry, 1998). The interpretation of 'A Raisin in the Sun' was to present it as a play concerning one's family's struggle for self-improvement despite its happening to be concerned a family of the black people. Rose (2014: 1) commented on this play as a reflection of it, claiming that, "although involving Negro characters, is essentially one that deals with common human problems confronting a family that happens to be black".

"What happens to a dream deferred?" The introduction of the play involves many poetic lines belonged to Langston Hughes's poem, 'Montage of a Dream Deferred'. The title A Raisins in the Sun is drawn from the introduction itself. The beginning of Hughes's poem, he poses a question concerning what comes out when one defers his/her own dream. Then, he further asks if or not such delayed dream(s) will 'dry up/ like a raisin in the sun?' In this regard, Hughes wrote 'Harlem" regarding the AfricanAmerican dream of righteousness, economic freedom of movement and right to use of power. Perhaps, the poet intends to say that the American dream, is the vision of a country in which every citizen has equality of rights. Or else, "Raisin" is a reminder of the previous question on the part of the poet that hasn't yet been replied to. The issue of a deferred dream is well-expressed - in the play - by all members of the Youngers family. Therefore, a reference is made by Hansberry to the deferring of dreams as the meaning is adopted using Hughes's poem as he says:

"What happens to a dream deferred?

Does it dry up like a raisin in the sun?

Or fester like a sore -- And then run?

Does it stink like rotten meat?

Or crust and sugar over -- Like a syrupy sweet? 


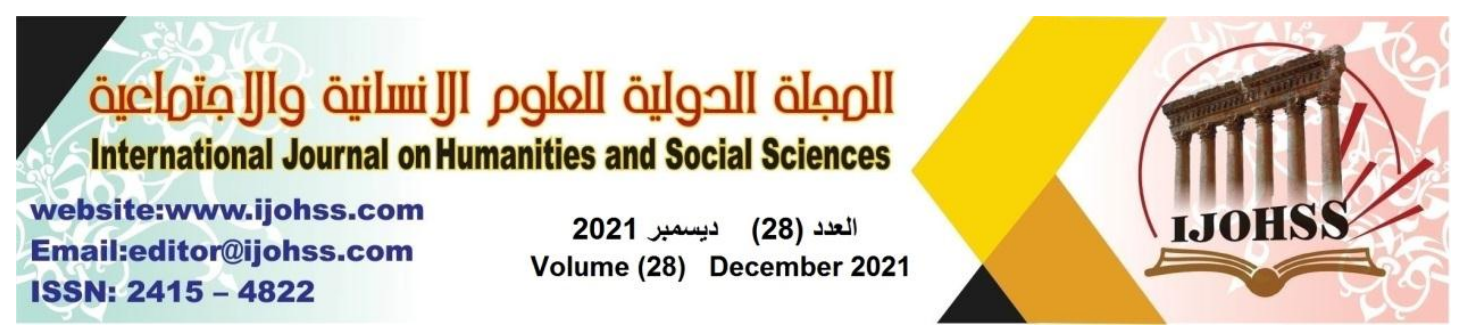

Maybe it just sags like a heavy load. Or does it explode?" (Hughes, 1990, p.26).

Hansberry's play 'A Raisin in the Sun' is considered as both a "Negro play" as well as a worldwide play. Such a fact is ascertained by the playwright commenting that:

"I don't think there is anything more universal in the world than man's oppression to man." She argued that her characters were Negro and specifically from Chicago's south side in order to use the specific to refer to the universal. She said: "one of the soundest ideas in dramatic writing is that, in order to create the universal, you must pay very great attention to the specific." (Terkel, 1961: 14).

Commonly, to 'dream' means to think of something to be achieved. In the U.S.A. this phenomenon is called the American Dream. When a dream is achieved, it then will cause a feeling of greatness and happiness as well as satisfaction. It may also lead to live the so-called high or prosperous life. That is to say, one's life is to be practiced wonderfully at all times. On the contrary, as such a dream is not achieved, the outcomes will not be more than a feeling of misery and unsuccessfulness. Here, the exact meaning of the American Dream may stand for the opportunity for success and prosperity through hard work.

In the United States of America, the American Dream is a national ethos, which is the set of ideals of freedom that involves the opportunity for prosperity and success, till an upward social mobility for the family and children. These successes are achieved by hard work in a society that is restricted by few barriers. The American ancestors believed this dream should come true for people can have a logic to fight for their country. It became a force that drives toward helping shape America's economic growth. A Raisin in the Sun is meant to fight against racism which keeps occurring. The Blacks stood against the long-lived separation however, they were encountering problems of race. The play represented the Youngers fighting in the face of such problems.

The play is about dreams, the many deeply desired and often conflicting dreams that are flying around in the Younger family, making everybody crazy. It narrates an important period in the lives of the Younger family: Beneatha comes to a better understanding of her origin, Walter learns how to be a man, his wife, Ruth, rediscovers hope, and Mama learns to be less controlling. Mama's dream has been to move to a better neighborhood, but they face racist opposition from local whites, led by Karl Lindner. The setting of this paly had been created by the playwright Lorraine Hansberry as to dream, to defer and to have a conflict. Concord of a family is touched by the human spirit, and overcomes - each character - all dreams have faced deferment. Usually, a life of a certain family is impacted by the accountabilities and letting Hansberry to warn deferments as a caution for Americans to wake up and listen.

"Walter to Mama: "What you need me to say you done right for? You the head of this family. You run our lives like you want to. It 


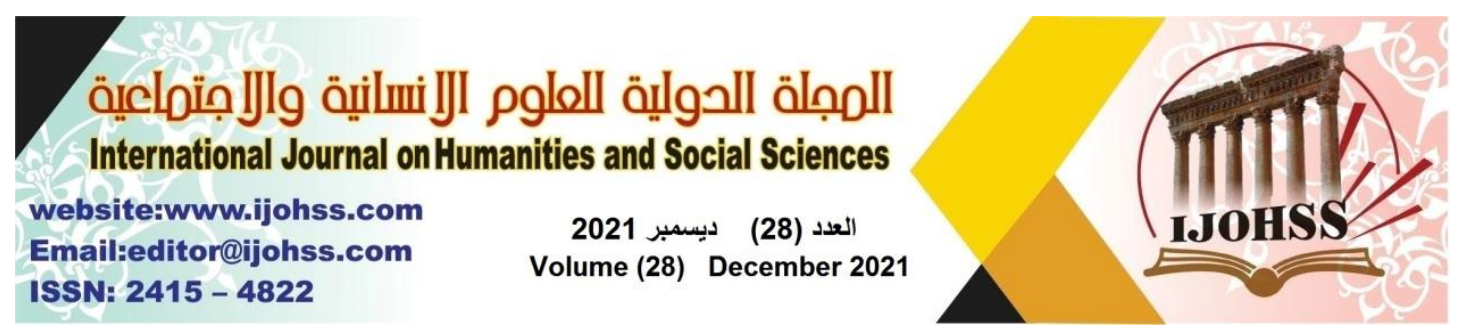

was your money and you did what you wanted with it. So what you need me to say it was all right for? So you butchered up a dream of mine-you-who always talking 'bout your children's dreams." (A Raisins in the Sun, p. 94, 95)

The Youngers' life was under segregation within a neighborhood that continues to be among the most isolated zones in the U.S.A. throughout the play, every act that is performed, shows the effects caused due to race. By the time the play was first staged in 1959, the Blacks and the Whites were yet isolated, and there were no contacts between the two parties. For example, Mama and her daughter-in-law Ruth appeared as maids for the White women. Even, her spouse Walter played the role of the White man's chauffeur. Walter is described as uninteresting and dismal discloses that Walter's job suppresses any sense of individuality or desire for initiative, that it positions him as utterly powerless". (Domina \& Hansberry, 1998, p, 21). Since the play is a demonstration of the status of "rich white" people that partially relies on their capability of employing men and women such as Walter, Ruth, and Mama as their servants. (Ibid). In addition, the restriction of the family of the Youngers is to their inadequately upheld flat due to they are of low-paid jobs and also the often absence of the landlords.

\section{Conclusion}

Lorraine Hansberry's 'A Raisin in the Sun' expresses - through analysis - moral concerns more than those related to economy and politics. It shows a picture which determines and set the right success. Hence, it can be said that the drama is a depiction of the Blacks to spiritually gain existence and pursuit for their African identity. The characters like Mama, Ruth and Walter - has their American Dream. Dreams are varied between those that can be achieved, while other cannot. This is due to some of the characters that have been dreaming must encounter some phenomenon related to racial discrimination as for poverty. As mama is a considerate, responsible and wise woman, she kept dreaming of owning a better housing. Prior to gaining the indemnity cash that comes from the late Mr. Younger's life indemnity, she pays the down payment of a house in a White's neighbourhood despite Walter disagreement with her idea. Obviously, she has power and courage as she decides to buy a house in the White's neighbourhood though the Blacks will face violence in case they want to shift in the Whites' neighbourhood.

\section{References}

1. Abbotson, S. C. (2003). Thematic guide to modern drama. Greenwood Press.

2. Adams, J. T., \& Schneiderman, H. (2017). The epic of America. Routledge.

3. Adams, R. J. (1935) the Record of America. New York: Charles Scribner's Son.

4. Althen, G., Doran, A. R., \& Szmania, S. J. (2003). American ways: A guide for foreigners in the United States. Yarmouth, ME: Intercultural Press.

5. Baldwin, J. (1989). Conversations with James Baldwin. Univ. Press of Mississippi. 


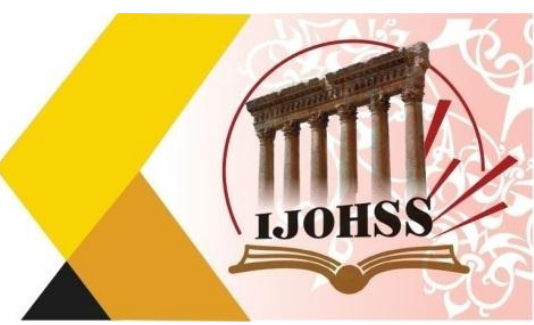

6. Bernstein, R. (1999). Inventing a fishbowl: white supremacy and the critical reception of Lorraine Hansberry's A Raisin in the Sun. Modern Drama, 42(1), 16-27.

7. Bloom, H., \& Hobby, B. (Eds.). (2009). the American Dream. InfoBase Publishing.

8. Bradbury, M., \& Temperley, H. (Eds.). (1998). Introduction to American studies. Longman Sc \& Tech.

9. Domina, L., \& Hansberry, L. (1998). Understanding a Raisin in the sun: A student casebook to issues, sources, and historical documents (Vol. 10). Greenwood.

10. Gale, C. L. (2018). A Study Guide for Langston Hughes's" Black Nativity". Gale, Cengage Learning.

11. Hansberry, L., \& Shay, M. (1974). A Raisin in the Sun (p. 146). Canadian National Institute for the Blind.

12. Hochschild, J. L. (1996). Facing up to the American dream. Princeton University Press.

13. Hughes, L. (1990). Harlem ("What happens to a dream deferred?").

14. Hughes, L. (2011). Selected Poems of Langston Hughes. Vintage.

15. Lemay, L. (1989). TA an Early American Reader. Washington D.C. 20547, United States Information Agency.

16. Parillo, V. N. (1994, December). Diversity in America: A sociohistorical analysis. In Sociological Forum (Vol. 9, No. 4, pp. 523-545). Kluwer Academic Publishers-Plenum Publishers.

17. Rose, T. (2014). Hansberry's A Raisin in the Sun and the "Illegible" Politics of (Inter) personal Justice. Kalfou, 1(1).

18. Scanlan, D. (1988). Reading Drama. Mayfield Publishing Company.

19. Schlesinger, A. M. (1948). American Dreams: A Study of American Utopias by Vernon L. Parrington, Jr. New England Quarterly, 21(1), 286.

20. Seiler, the Promised Land, p. 15. (URL: www.facts-are-facts.com/magazin/1promisedland.) Retrieved 15th July, 2017.

21. Seiler, the Promised Land, p. 18.

22. Spiller, R. E., Thorpe, W., Johnson, T. H., \& Canby, H. S. (1949). Literary history of the United States. Science and Society, 13(4).

23. STAFF, M. W. (1995). Merriam-Webster's encyclopedia of literature. Merriam-Webster.

24. Sunstein, C. R. (2003). The Declaration of Independence and the Constitution of the United States of America. Georgetown University Press.

25. Terkel, S. (1961). An Interview with Lorraine Hansberry. WFMT Chicago Five Arts Guide, 10(4), 8-14. 